\title{
IMPROVEMENT OF TECHNICAL AND ECONOMIC INDICATORS OF TOOL PREPARATION \\ AT MANUFACTURING ENGINEERING PRODUCTION BY THE IMPROVEMENT OF REGULATORY BASIS
}

\section{ПІДВИЩЕННЯ ТЕХНІКО-ЕКОНОМІЧНИХ ПОКАЗНИКІВ ІНСТРУМЕНТАЛЬНОЇ ПІДГОТОВКИ МАШИНОБУДІВНОГО ВИРОБНИЦТВА ШЛЯХОМ ВДОСКОНАЛЕННЯ НОРМАТИВНОЇ БАЗИ}

\section{Viliam Zaloga ${ }^{1}$ \\ Yuliia Denysenko}

DOI: https://doi.org/10.30525/978-9934-588-15-0-54

Abstract. One of the most important areas of activity of manufacturing engineering production is its tool preparation (TP), the purpose of which is to provide all (without exception) processes that accompany the production and sale of products with the necessary tools and equipment. Therefore, improving the regulatory framework for the management and quality assessment of TP is in the context of the functioning of information technology is an urgent scientific and applied task, the solution of which will improve the efficiency of production, including increasing reliability, reducing costs and reducing the time to prepare the engineering enterprise in the field of tooling. In today's market relations, an efficient enterprise and competitive advantages can only be provided by an efficient system of managing its production activity based on the widespread use of modern information technologies, which is an important source of improving the effectiveness of the decisions made, productivity and competitiveness of production. The aim is to increase the efficiency of the system of TP of engineering enterprises by improving its regulatory support on the basis of forecasting its technical and economic indicators (TEI) in the conditions

${ }^{1}$ Doctor of Technical Sciences, Professor,

Head of Department of Manufacturing Engineering, Machines and Tools,

Sumy State University, Ukraine

${ }^{2}$ Candidate of Technical Sciences, Senior Lecturer,

Sumy State University, Ukraine 
of use of modern information technologies. One of the main tasks of the research is to develop mechanisms and toolkits to create a model of TP quality management in the context of information technologies, based on the application of forecasting and optimization methods. The object of the research is the quality management system of the tool preparation. The subject of the research is to ensure regulatory of TP quality management in the conditions of introduction of information technologies. Theoretical studies are based on the use of TQM principles in managing the quality of the TP information system (ISTP). Fundamental provisions of the basics of the theory of quality management, the theory of decision making, qualimetry and others were used to solve scientific problems. For the first time, the model of information system of TP quality management at engineering enterprise is proposed on the basis of the analysis of the toolkits adopted in CALS technologies at each stage of the life cycle of the corresponding products, which allows to identify information flows using modern information technologies. The features of TP of machine-building enterprises, which became a prerequisite for the development of common methods in making decisions about the quality of its processes, are defined in the paper. The paper presents a unified model of decision making in the field of quality of processes of ISTP with a dimensionless scale of evaluation, which allows to evaluate processes under one of two conditions, depending on the TEI of processes and the cost of quality of ISTP processes. Taking into account the requirements of ISTP, the TEI system was proposed on three grounds of optimality and the classification of costs for the quality of ISTP processes was developed, which significantly improves the efficiency of its functioning. The algorithm of introduction of ISTP in an engineering enterprise is scientifically substantiated and developed. It is shown that the proposed regulatory and methodological support allows for each engineering enterprise to develop a quality management system of ISTP taking into account the specificity of the enterprise, the totality of technological processes, the nature of technological equipment, and other production features.

\section{1. Вступ}

В умовах ринкових відносин сучасному машинобудівному підприємству ефективне функціонування й конкурентні переваги може забезпечити тільки ефективна система управління його виробничою діяль- 
ністю. Сьогодні підприємство саме повинне визначати й прогнозувати, вміти швидко, а головне правильно реагувати на будь-які зміни в зовнішньому й внутрішньому середовищі, і відповідно до них корегувати свою діяльність. Ускладнення виробництва, супроводжуване ростом складності розв'язуваних завдань і підвищенням втрат від неточного й несвоєчасного прийняття рішень, висуває необхідність удосконалювання методів оперативного управління виробництвом.

У комплексі процесів виробництва на сучасних машинобудівних підприємствах важливу роль відіграє інструментальна підготовка виробництва, тому що від якості й прогресивності інструмента й оснащення, своєчасного забезпечення ними робочих місць залежить і ефективність діяльності підприємства в цілому. Це пов'язане 3 тим, що витрати на науково-технічне оснащення в масовому виробництві досягають 25-30\% ціни устаткування, у великосерійному - 10-15\%, у дрібносерійному й одиничному - у межах 5\%. Частка витрат на оснащення в собівартості досягає відповідно 4, 6, 8 і 15\%. Розмір капіталовкладень в інструмент і оснащення коливається від 15 до 40\% від суми коштів підприємства.

Крім того, трудомісткість проектування й виготовлення комплекту необхідного інструменту та технологічного оснащення (ТО) в загальних витратах на технологічну підготовку виробництва нових виробів машинобудівної галузі становить до 80\% [1].

Специфіка ІПВ обумовлюється тим, що на сучасних підприємствах застосовується оснащення десятків і сотень тисяч найменувань, що у свою чергу в сотні раз перевищує номенклатуру виробів, що випускаються. В інструментальному господарстві задіяно безліч відділів і цехів, які займаються проектуванням, виробництвом, закупівлею, ремонтом і відновленням оснащення, доставкою іiі на робоче місце тощо. Це спричиняє складності як у забезпеченні оснащенням основного виробництва, так і в моніторингу процесів системи ІПВ, особливо в умовах оперативного управління основним виробництвом.

Наведені дані дають уявлення про важливість управління процесами IПВ для досягнення ефективної роботи машинобудівного підприємства.

Таким чином, керівництво сучасних підприємств, перебуваючи в пошуку нових підходів у управлінні й підвищенні якості прийнятих рішень, натрапляє на граничні можливості застосовуваних методів і алгоритмів. 
Інструментальне виробництво в наш час $є$ одним із основних споживачів ринку CAD/CAM-систем і послуг (до 30\%) [2, с. 23]. Це положення вимагає підвищеного уваги й створює передумови для використання одного 3 перспективних шляхів - застосування інформаційних технологій.

Сучасні інформаційні технології є важливим джерелом підвищення ефективності прийнятих рішень, продуктивності й конкурентоспроможності. Їхнє застосування пов'язане з одержанням і обробкою інформації про внутрішні матеріальні потоки, характеристики виробничих процесів, контролі ходу виробництва, випуску готової продукції, вантажних відправленнях, параметрах замовлень і інших характеристиках.

Тому вдосконалення нормативного забезпечення управління й оцінки якості IПВ в умовах функціонування інформаційних технологій $\epsilon$ актуальним науково-прикладним завданням, вирішення якого забезпечить підвищення ефективності виробництва, включаючи підвищення надійності, зниження витрат і скорочення часу на підготовку машинобудівного підприємства з питань інструментального забезпечення.

Мета і задачі дослідження. Метою дисертаційної роботи є підвищення ефективності системи інструментальної підготовки виробництв машинобудівних підприємств шляхом удосконалення іiі нормативного забезпечення на основі прогнозування її техніко-економічних показників (ТЕП) в умовах використання сучасних інформаційних технологій.

Для досягнення поставленої мети було сформульовано і вирішено наступні задачі дослідження:

- проаналізувати сучасний стан нормативного забезпечення процесів управління й оцінювання якості ІПВ та впровадження сучасних інформаційних технологій при інструментозабезпеченні машинобудівних підприємств;

- проаналізувати сучасні методи прогнозування й розробити рекомендації щодо їх раціонального вибору для управління якістю процесів життєвого циклу ІПВ;

- розробити механізми й інструментарії створення моделі управління якістю ІПВ в умовах інформаційних технологій, що базуються на застосуванні методів прогнозування й оптимізації;

- розробити принципи побудови нормативного забезпечення якості процесів ІПВ на основі запропонованої прогнозно-оптимізаційної моделі управління якістю; 
- провести апробацію запропонованих рекомендацій і розроблених методик у виробничих умовах.

Об'єкт дослідження: система управління якістю процесів інструментальної підготовки виробництва.

Предмет дослідження: нормативне забезпечення управління якістю ІПВ в умовах впровадження інформаційних технологій.

Методи дослідження: Теоретичні дослідження базуються на використанні принципів ТQМ при управлінні якістю інформаційної системи IПВ (IC IПВ). Для вирішення наукових завдань були використані фундаментальні положення основ теорії управління якістю, теорії ухвалення рішень, кваліметрії, технології машинобудування й інструментального виробництва. Для аналізу, збору та обробки інформації використовувалися методи статистичного аналізу і експертних оцінок.

Достовірність наукових положень, висновків і рекомендацій підтверджена експериментальними дослідженнями, які реалізувалися за допомогою існуючих методів обробки статистичних даних, кваліметрії та сучасного програмного забезпечення.

Наукова новизна одержаних результатів полягає в удосконаленні наукових підходів до управління якістю інструментальної підготовки виробництва промислових підприємств в умовах сучасних інформаційних технологій. Це базується на наступних наукових розробках.

Вперше:

- на основі узагальнення вітчизняного та зарубіжного досвіду 3 управління якістю продукції і процесів машинобудівних підприємств та логіко-структурного аналізу отриманої інформації запропонована система ТЕП ІПВ, яка дозволяє організувати ефективну систему збору, опрацювання й ефективного використання техніко-економічної інформації у конкретних виробничих умовах;

- запропоновано модель інформаційної системи управління якістю інструментальної підготовки виробництва машинобудівного підприємства на основі аналізу прийнятих у CALS-технологіях інструментаріїв на кожному етапі життєвого циклу відповідної продукції, яка дозволяє ідентифікувати інформаційні потоки з використанням інформаційних технологій;

- запропоновано узагальнений показник інформаційної системи IПВ, який дозволяє оцінити результативність та ефективність функціо- 
нування даної системи у відповідності з виконанням вимог міжнародних стандартів на системи управління (ISO 9001, OHSAS 18001 і т.д.);

Одержали подальший розвиток:

- підхід до класифікації витрат на якість IC IПВ машинобудівного підприємства, що дозволило з урахуванням запропонованої типової моделі управління якістю IC IПВ в умовах функціонування інформаційних технологій виділити статті витрат на якість процесів IПВ та розробити універсальну класифікацію витрат на якість, підприємств машинобудівної галузі;

- підхід до побудови шкал оцінювання ТЕП, що дозволяє шляхом застосування нечітких множин мати можливість узгоджувати неоднорідні ТЕП ІС ІПВ в умовах використання єдиного інформаційного простору;

- модель вибору раціональних рішень з управління якістю інструментальної підготовки виробництва машинобудівного підприємства, яка дозволяє на основі використання теорії оптимізації на графі прогнозувати витрати на інструментальне забезпечення основного виробництва з урахуванням виконання обмежень за рівнем якості технологічного оснащення та інструменту по розташовуваним матеріальним i тимчасовим ресурсам в умовах впровадження інформаційних технологій (трирівнева система прийняття раціональних рішень).

Практичне значення одержаних результатів. Запропонований коефіцієнт сталого розвитку процесів IC IПВ, який базується на використанні статистичних даних, дозволяє врахувати фактори, що впливають на ефективне функціонування IC IПВ.

Розроблені: «Типова методика прийняття рішень з управління процесами якістю IC IПВ багатономенклатурних машинобудівних підприємств», СОУ «Експлуатація технологічного оснащення в умовах функціонування інформаційних систем», а також СОУ «Інструментальна підготовка виробництва в інформаційній системі управління», які $\epsilon$ універсальними нормативними документами та базуються на використанні принципів TQM з врахуванням основних засад функціонування CALS-технологій.

Результати досліджень використано для вдосконалення процесу управління якістю процесів IC IПВ на ПАТ «Сумське машинобудівне науково-виробниче об'єднання», ВАТ НВП «Насостехкомплект» та показників 
навчального процесу СумДУ при розробці навчальних дисциплін: «Системи управління якістю» та «Управління інформаційними зв'язками» для студентів спеціальності «Якість, стандартизація та сертифікація».

\section{2. Сучасний стан проблеми управління якістю процесів ІПВ}

Огляд сучасних підходів до створення та використання систем ІПВ та IC IПВ в Україні досить детально викладено в роботах О.В. Івченко [3, с. $15-38 ; 4$, с. 239], I.В. Костюка [5, с. 10], О.Д. Динник [6, с. 65] та інших. Їх вивченням займаються ряд вчених, наприклад,: А.І. Левін [7, с. 612]. Інформаційному забезпеченню на промислових підприємствах присвячені роботи В.О. Вайсмана [8, с. 10], В.А. Окулесського [9, с. 7], Н.О. Чорної [10, с. 97] та інших. На основі аналізу праць вказаних та інших вчених, а також нормативного забезпечення інформаційних систем управління підприємством визначено сучасний стан проблеми управління ІПВ на вітчизняних підприємствах.

У ході проведених досліджень було встановлено, що сучасні інформаційні системи розглядають IПВ, як матеріальний ресурс, i майже не враховують, що на вітчизняних машинобудівних підприємствах хоч постійно і зростає питома вага покупних інструментів та інструментального оснащення, ще значну частину інструментального господарства займає інструмент і оснащення власного виготовлення. Отже, у такому випадку можуть бути застосовні принципи управління підприємством в цілому, тобто модулі CALS-технологій [11; 12, с. 58], що стосуються кожного етапу ЖЦ продукції й забезпечення ії якості, враховуючи вказану специфіку IПВ.

Крім того, вимоги й принципи до систем ERP і інших інструментів CALS-технологій, як правило, не забезпечують аналізу можливих ризиків і попередження збоїв. Тому, одним з напрямків по поліпшенню діяльності машинобудівного підприємства, пов'язаної з інструментозабезпеченням, $\epsilon$ розробка нормативного забезпечення системи IПВ на основі впровадження інформаційних технологій при можливості застосування на їх базі методів прогнозування й оптимізації відповідних процесів в системі ІПВ.

В розвиток методологій прогнозування якості процесів зробили вклад такі вчені, як: Дж. Бокс та Г. Дженкінс [13, с. 18], І.В. Антохонова [14, с. 8], Дж. Ханк, А. Райз та Дін Уічерн [15, с. 83] та інші. На основі праць зазначених вчених та узагальнення світового та вітчизняного досвіду представлена класифікація методів прогнозування по ступеню формалізації. 
Також аналіз сучасних тенденцій у управлінні підприємством показав, що нормативне забезпечення системи ІПВ в умовах застосування сучасних досягнень в області інформаційної підтримки виробництва повинне не тільки забезпечувати вимоги й принципи стандартів CALS-технологій, але й враховувати вимоги й принципи стандарту ДСТУ EN ISO 9001:2018. Впровадження цих стандартів спонукає сучасні підприємства України чітко контролювати витрати на підприємстві. Важливим елементом системи управління витратами на підприємстві $\epsilon$ аналіз і оцінка витрат на якість його процесів. Тому в розділі були проаналізовані підходи до визначення витрат на якість, що були запропоновані Г.Г. Азгальдовим [16, с. 16, 54], Дж. Джураном, Ф.Б. Кросбі [17; 18, с. 17], А.В. Фейгенбаумом [19, с. 18] та ін. Узагальнивши вітчизняний та зарубіжний досвід в управлінні витратами на якість були виділені основні системи класифікації витрат на якість.

Таким чином, здійснений аналіз сучасних інформаційних систем управління, методів прогнозування та систем класифікацій витрат на якість вказує на актуальність розробки методів, алгоритмів та методик управління IПВ, які б були застосовні на всіх процесах життєвого циклу системи, та враховували усі значущі на певному етапі показники функціонування процесів.

\section{3. Розроблення моделі управління якістю ІПВ}

Для організації ефективного управління процесами IПВ необхідно обов'язково розробляти, впроваджувати й підтримувати інформаційну систему управління якістю ІПВ. Загальна модель інформаційної системи управління IC IПВ, яка розроблена відповідно до вимог ДСТУ EN ISO 9001:2018 (рис. 1a), поєднує процеси життєвого циклу інструменту та оснащення, управління ресурсами IПВ, виміру, іiі аналізу й поліпшення (як на тактичному, так і на оперативному рівнях) у єдиному інформаційному просторі. Разом з тим, для сучасних багатономенклатурних промислових підприємств, особливо машинобудівного профілю, з метою підвищення ефективності інструментозабезпечення нагальним $є$ питання розробки та впровадження системи управління ІПВ підприємства на основі процесного підходу. В роботі запропоновані концептуальна модель інформаційної системи управління якістю IПВ (IC IПВ) саме з позиції процесного підходу, яка представлена на 
рис.1б у вигляді трьох взаємозалежних моделей систем ІПВ: організаційної, інформаційної та управління якістю.

Окрім створення та впровадження систем управління різними видами діяльності (системи управління якістю, системи управління охороною навколишнього середовища та ін.) $є$ доцільним розроблення системи техніко-економічних показників саме для IC IПВ (далі - ТЕП) $[20$, с. $62 ; 21$, c. 79$]$.

Ці ТЕП повинні бути: значущі, пов'язані $з$ іншими показниками в системі управління виробництвом основної продукції, прості та вимірні та щоб їх можна було порівнювати з аналогічними показниками інших підрозділів підприємства.

Тому в роботі запропоновано розподіл ТЕП IC IПВ за видами діяльності: організаційно-економічні, виробничі, управління якістю, екологічні та соціальні.

Окрім видів діяльності зазначені ТЕП рекомендовано класифікувати за рівнем управління процесами IC IПВ - ТЕП організаційного та тактичного рівнів, - а також за результуючим оптимальним значенням ТЕП: відносні, що знаходяться в інтервалі 0 - 1 (оптимальне значення 1); ТЕП, що визначаються згідно логічних суджень експертів.

Впровадження міжнародного стандарту ДСТУ EN ISO 9001:2018 і побудова промислового виробництва на базі процесного підходу в умовах функціонування інформаційних технологій спонукає сучасні підприємства у любий необхідний час контролювати витрати фінансових ресурсів на підприємстві. Тому, одними із важливих елементів створюваної системи ТЕП на підприємстві $\epsilon$ процеси аналізу і оцінки витрат на якість ІПВ. Чіткий та повний зміст запропонованої класифікації забезпечує основу аналізу та моделювання інформаційних потоків IПВ, що є дієвим інструментом з реалізації циклу Джурана-Демінга. Крім того, необхідність класифікації витрат обумовлена неоднорідністю різних видів витрат за складом, змістом, роллю у виробничому процесі, зв'язку з обсягом виробництва та ін. Показано, що класифікацію витрат на якість процесів ІПВ, побудовану на вказаних принципах, можна ефективно використовувати в управлінні IC IПВ.

Розроблена система класифікації витрат на якість процесів IC IПВ базується на принципах: істотності і стабільності; стандартизації; пристосовності; причинно-наслідкового зв'язку. 


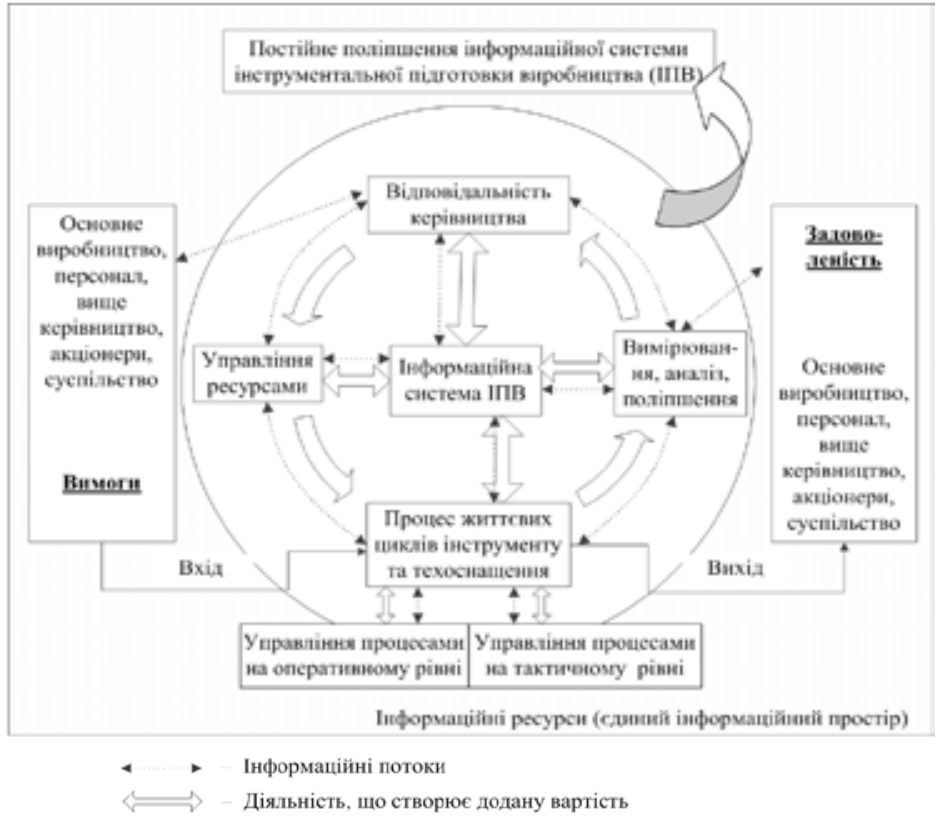

a)

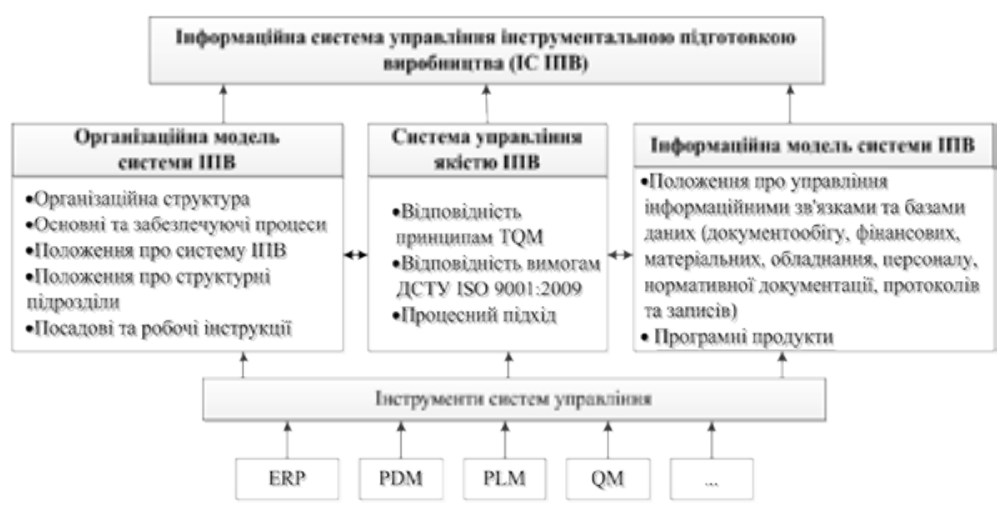

6)

Рис. 1. Загальна модель інформаційної системи управління

IC IПВ (a) та концептуальна модель системи управління IПВ в умовах застосування інформаційних технологій (б) 
Для проектування класифікації запропоновано використовувати метод ранжування експертних оцінок, який грає роль з'єднувальної ланки між умовами реального процесу IC IПВ та оптимальною системою класифікації витрат. На рис. 2 представлений фрагмент класифікація витрат, розробленої на основі проведених досліджень з опитування восьми експертів за розробленою у роботі методикою.

Однією з переваг запропонованої моделі IC IПВ, яка відповідає вимогам стандартів CALS-технологій, є створення єдиного інформаційного простору, що значно спрощує обмін інформацією, а також збір необхідних даних. Крім того, системи управління, що базуються на принципах CALS-технологій дозволяють створювати великі масиви вихідних даних в найкоротші строки. Інформація, що отримується про ТЕП з баз даних IC IПВ, є відмінною основою для прийняття стратегічно важливих для керівників рішень в області якості. В основі прийняття рішення пропонується цільова функція оптимізації - функція визначення коефіцієнта сталого розвитку IC IПВ $-\mathrm{K}_{\text {ст. }}$.

Цільова функція має вигляд:

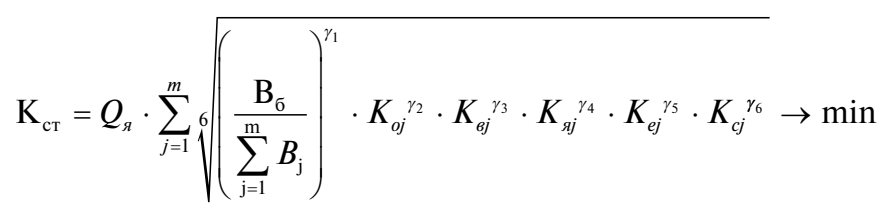

де $Q_{q}$ - показник якості процесу IC IП; $B_{j}$ - витрати на якість процесів ІПВ; $B_{\sigma}-$ базовий показник витрат на якість процесів IПВ; $K_{o}$, $K_{g}, K_{я}, K_{e}, K_{c}-$ коефіцієнти комплексних ТЕП, відповідно: організаційно-технічний, виробничий, якості процесів ІПВ, екологічний та соціальний, які розраховуються для кожного процесу життєвого циклу IПВ; $\gamma_{1} \ldots \gamma_{6}-$ показники вагомості відповідних комплексних ТЕП.

Алгоритм прийняття рішень в запропонованій IC IПВ показаний на рисунку 3. В основі цього алгоритму лежить процес прийняття рішень в IC IПВ, який забезпечує виконання двох найбільш розповсюджених умов: виконання діяльності з мінімальними витратами (найбільш розповсюджена умова) та мінімізація часу виконання встановлених в IC IПВ задач. Тому в для прийняття рішень вибору раціональної стратегії по забезпеченню ТО передбачене виконання двох взаємовиключних блоків (блоки 3 і 4). При виконанні блоку 3 (перша умова) цільовою 


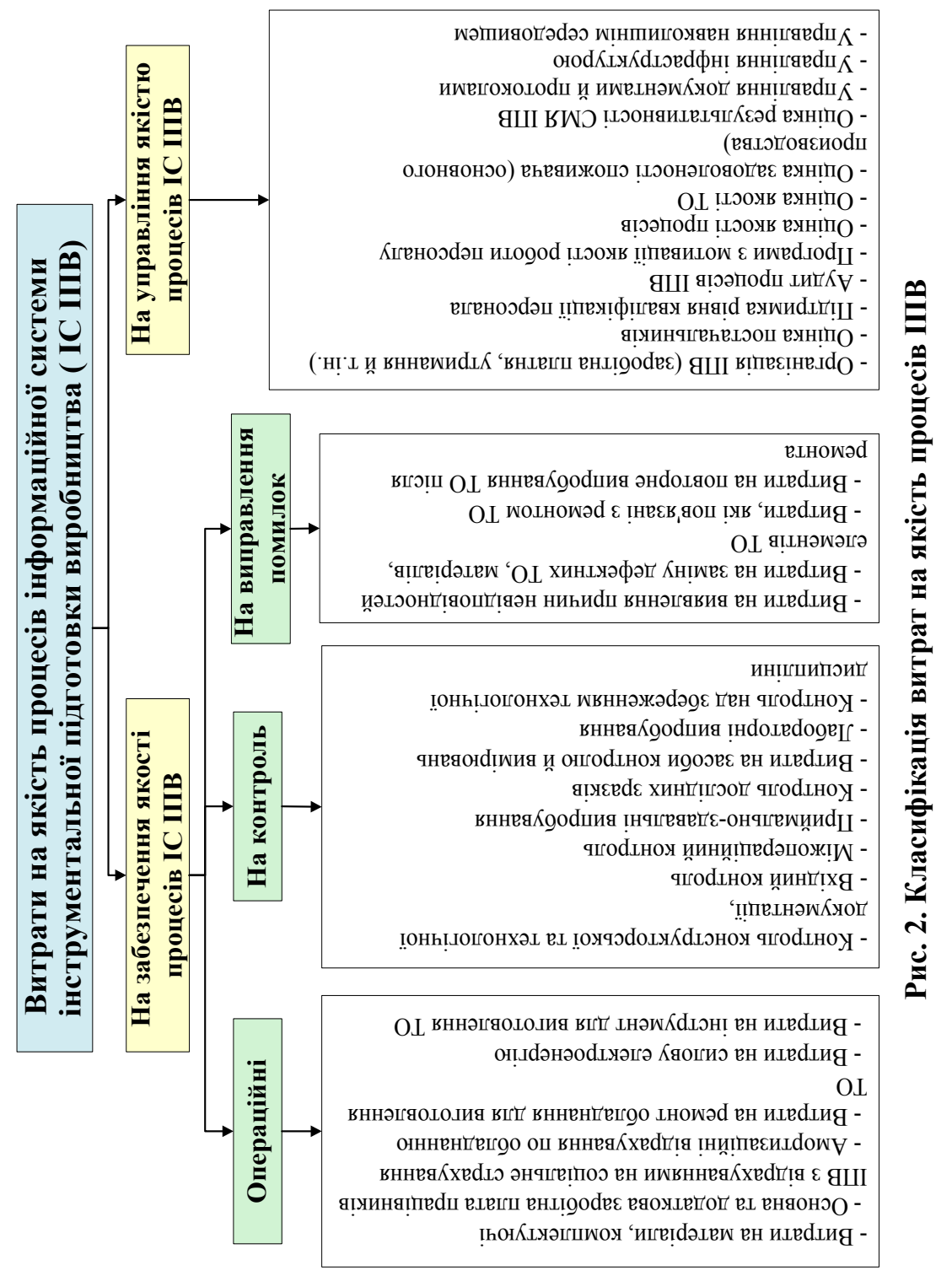


функцією виступає коефіцієнт сталого розвитку IC IПВ, а час - одна із обмежуючих умов. При виконанні блоку 4 (друга умова) цільовою функцією $є$ мінімізація часу при одній із обмежуючих умов - коефіцієнт сталого розвитку IC IПВ. Задача прийняття раціональних рішень зводиться до застосування методу оптимізації на графі - знаходження найкоротшого шляху. Основним при вирішенні задачі знаходження найкоротшого шляху є алгоритм Дейкстри, який вважається одним 3 найбільш ефективних алгоритмів при вирішенні завдання знаходження на графі найкоротшого шляху між двома виділеними вершинами.

Блок 5 (рис. 3) передбачає обчислення ймовірності реалізації обраної стратегії з допомогою застосування теорії марківських ланцюгів. Якщо значення розрахованої ймовірності менше рівня, який задовольняє особу, що приймає рішення, в такому разі необхідно розглянути альтернативні стратегії перебігу процесів IC IПВ.

У блоці 6 на основі отриманої з блоків 3, 4 та 5 інформації, особа, що приймає рішення, обирає рекомендовану стратегію розвитку процесів ІС ІПВ.

Необхідно відмітити, що з метою підвищення ТЕП ІС ІПВ при застосуванні запропонованої моделі передбачено визначення раціональної стратегії при підстановці ТЕП ІС ІПВ із підвищеними значеннями.

У зв'язку $з$ можливою неузгодженістю між різними ТЕП (різні критерії, різні розмірності тощо) у запропонованій класифікації для визначення коефіцієнту сталого розвитку запропоновано проводити їх нормалізацію, тобто переводити в безрозмірні величини - бали (табл. 1) у відповідності зі значенням лінгвістичної змінної ТЕП (рис. 4).

Таблиця 1

Шкала оцінювання ТЕП процесів ІС ІПВ

\begin{tabular}{|c|c|c|}
\hline Значення ТЕП & $\begin{array}{c}\text { Значення лінгвістичної } \\
\text { змінної «ТЕП» }\end{array}$ & Бал \\
\hline $\mathbf{1}$ & $\mathbf{2}$ & $\mathbf{3}$ \\
\hline $0 \leq u \leq 0,2$ & Дуже добре & 1 \\
\hline $0,2<u \leq 0,34$ & Добре & 2 \\
\hline $0,34<u \leq 0,66$ & Задовільно & 3 \\
\hline $0,66<u \leq 0,8$ & Погано & 4 \\
\hline $0,8<u \leq 1$ & Дуже погано & 5 \\
\hline
\end{tabular}




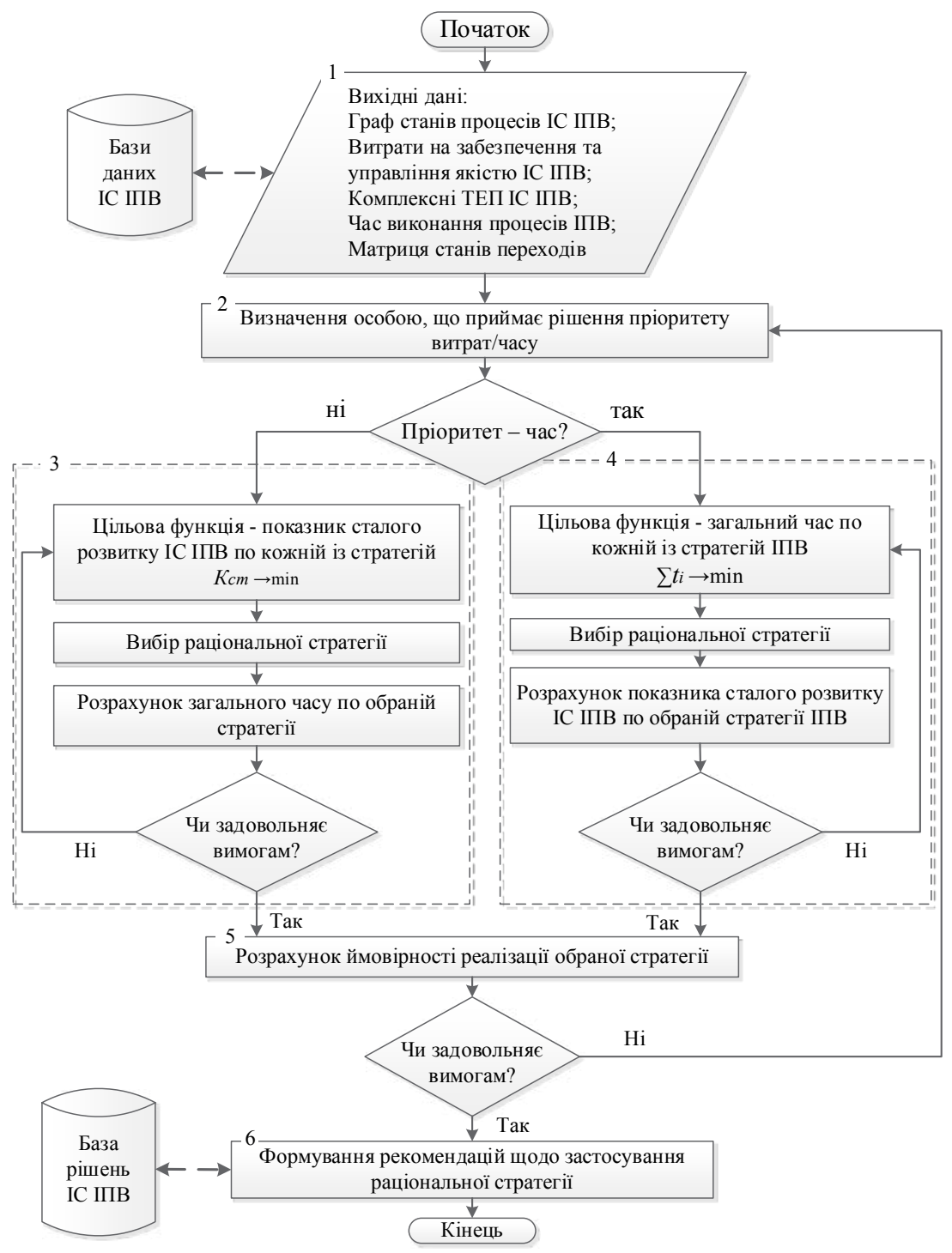

\section{Рис. 3. Блок-схема реалізації математичної моделі щодо прийняття рішень в IC IПВ}


Viliam Zaloga, Yuliia Denysenko

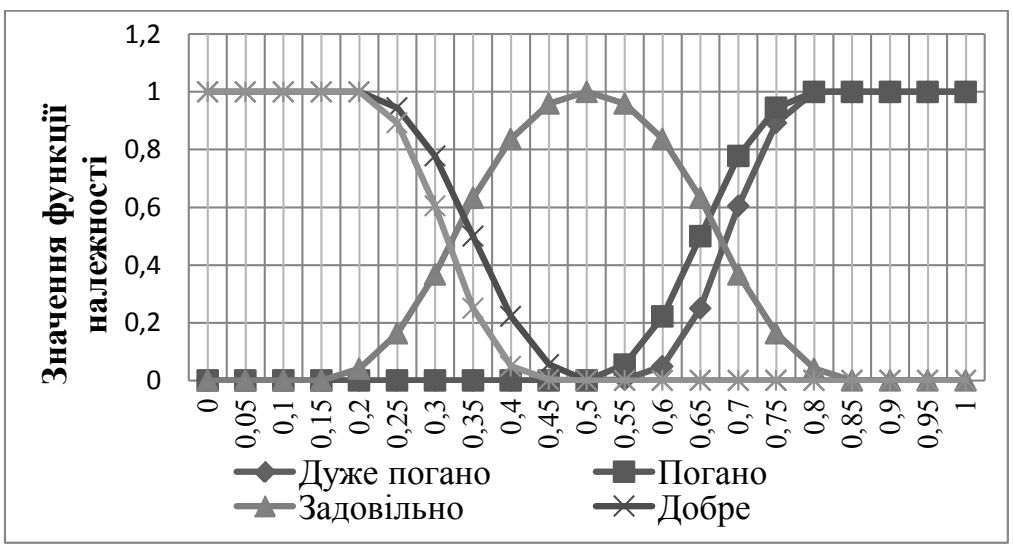

Рис. 4. Графічне зображення лінгвістичної змінної «ТЕП»

\section{4. Аналіз основних етапів алгоритму прийняття рішень в IC IПВ}

Єдину шкалу нормалізації ТЕП системи ІПВ запропоновано розробляти на основі застосування теорії нечітких множин. Методика застосування математичного апарату теорії нечітких множин включає такі основні етапи: виділення параметрів, які характеризують досліджувану систему; визначення і формалізація лінгвістичних оцінок параметрів (фазифікація); побудова нечіткої бази знань про взаємозв'язки між параметрами; реалізація нечіткого логічного висновку про вплив вхідних параметрів на вихідні фактори; перетворення нечіткого логічного рішення в чітке значення (дефазифікація).

За основу взята шкала Харрінгтона, яка при прийнятті багатьох рішень дозволяє оцінювати будь-який показник за його наступними рівнями: дуже добре - 1; добре - 2; задовільно - 3; погано - 4; дуже погано - 5. Побудова функцій належності за зазначеними рівнями дає можливість графічно зобразити лінгвістичну змінну «ТЕП», як показано на рис. 4 та побудувати нормалізовану шкалу оцінювання ТЕП щодо кожного процесу життєвого циклу IC IПВ

Алгоритм прийняття рішень в IC IПВ складається 3 наступних основних етапів.

1. Визначення вихідних даних. Вихідні дані формуються в єдиній базі даних інформаційної системи підприємства. 
Вихідними даними для прийняття раціонального рішення щодо процесів IC IПВ $є$ прогнозовані значення витрат на забезпечення та управління якістю IC IПВ (на основі застосування раціональних методів прогнозування (рис.3) та комплексних техніко-економічних показників IC IПВ (виражених в балах), прогнозний час виконання процесів IC IПВ, а також матриця переходів станів процесів IC IПВ.

2. Побудова моделі станів процесів IC ІПВ.

Модель управління IC ІПВ, представляється у вигляді орієнтованого графу $\mathrm{G}(\mathrm{S}, \mathrm{t})$, де $\mathrm{S}$ - впорядковані пари вершин, a t - це дуги, що їх з'єднують [22, с. 11].

Граф станів процесів IC IПВ представлений на рис. 5.

3. Визначення пріоритету «стійкість IC IПВ/час» особою, що приймає рішення.

Прийняття рішень засновується на виконанні двох умов:

а) виконання діяльності з мінімальними витратами (найбільш розповсюджена умова);

б) мінімізація часу виконання встановлених задач в IC IПВ.

Для прийняття рішень вибору раціональної стратегії по забезпеченню ТО передбачене виконання двох взаємно виключних блоків (рис. 3) - блок 3 для умови а) і блок 4 для умови б).

Прийняття раціонального рішення проводиться методом оптимізації на графі з застосуванням алгоритму Дейкстри.

Блок 3 реалізує стратегію виконання діяльності з мінімальними витратами при забезпеченні необхідного рівня ТЕП IC IПВ, тобто реалізує стратегію забезпечення сталого розвитку ІПВ. Для виконання блоку 3 цільова функція оптимізації - функція визначення коефіцієнта сталого розвитку IC IПВ, який визначається за формулою цільової функції (1), в якій коефіцієнти $K_{o}, K_{g}, K_{g^{\prime}} K_{e}, K_{c}$ розраховуються для кожного процесу життєвого циклу ІПВ за формулою:

$$
K=\sum_{i=1}^{n}\left(k_{i}\right)^{\frac{1}{n}},
$$

Блок 3 реалізує стратегію виконання діяльності з мінімальними витратами при забезпеченні необхідного рівня ТЕП IC IПВ, тобто реалізує стратегію забезпечення сталого розвитку ІПВ. Для виконання блоку 3 цільова функція оптимізації - функція визначення коефіцієнта 


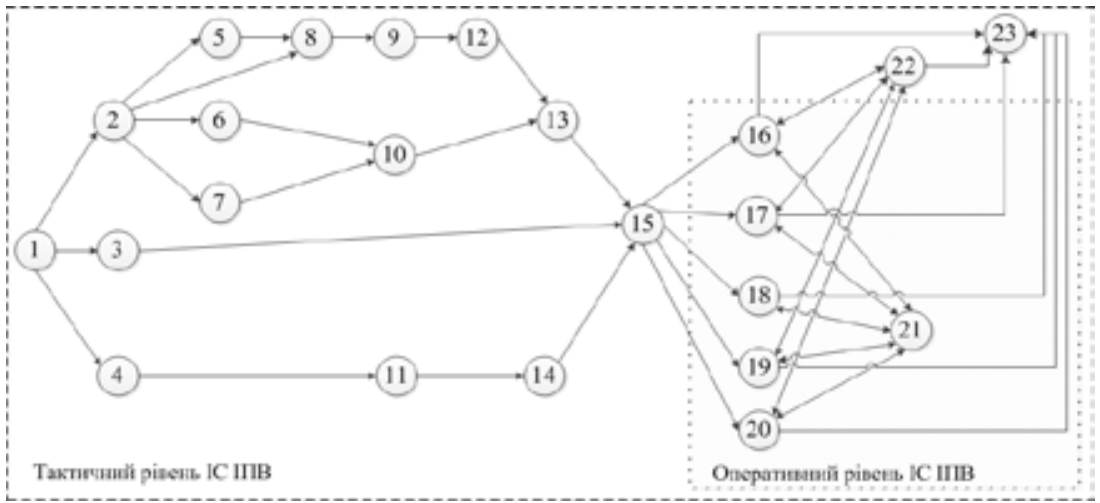

1 - виявлення потреб в ТО, її уніфікації та нормативному забезпеченні; 2 - прий-няття рішення про виготовлення, модернізацію ТО чи використання збірного ТО; 3 - прийняття рішення про використання ТО, що є в наявності; 4 - прийняття рішення про закупівлю уніфікованого ТО; 5 - розроблення проекту на виготовлення ТО; 6 - розроблення проекту на модернізацію ТО;

7 - розроблення проекту на складання ТО; 8 - підготовка плану випуску ТО;

9 - закупівля матеріалів; 10 - закупівля комплектуючих; 11- закупівля ТО;

12 - виготовлення ТО; 13 - приймально-здавальні випробування ТО;

14 - приймальні випробування ТО; 15 - зберігання ТО; 16 - прокат виготовленого ТО; 17 - прокат модернізованого ТО; 18 - прокат збірного ТО;

19 - прокат ТО, що є в наявності; 20 - прокат придбаного ТО;

21 - централізоване заточування інструменту; 22 - ремонт ТО; 23 - утилізація ТО.

\section{Рис. 5. Граф станів процесів IC IПВ}

сталого розвитку IC IПВ, який визначається за формулою цільової функції (1), в якій коефіцієнти $K_{o}, K_{g}, K_{я}, K_{e}, K_{c}$ розраховуються для кожного процесу життєвого циклу ІПВ за формулою:

Витрати на процес життєвого циклу ТО приймаються на одиницю ТО, тобто планові витрати на якість процесів IC IПВ розраховуються за формулою:

$$
B=\frac{\sum_{i=1}^{m}\left(B_{3 i}+B_{y i}\right)}{K_{T O}},
$$

де $B_{3 i}$ - плановані витрати на забезпечення якості процесу IПВ;

$B_{3 i}$ - плановані витрати на управління якістю процесу IПВ;

$\mathrm{m}$ - кількість статей калькуляції витрат на якість процесу IПВ;

$K_{T O}$ - кількість ТО, щодо процесу ЖЦ якого приймається рішення. 
Примітка 4. На тактичному рівні IC IПВ кожен процес спонукає витрати, які несуть негативну цінність, а на оперативному рівні, навпаки. Тому для оперативного рівня ІПВ пропонується відносити витрати на якість процесів ІПВ до кількості ремонтів чи переточувань.

Хоча процес переточування інструменту чи ремонту ТО і несе за собою витрати на якість, збільшення кількості переточувань збільшує цінність інструменту (збільшується строк окупності витрат, які закладені в виготовлення чи придбання ТО).

Таблиця 2

\section{Система ТЕП на тактичному рівні}

\begin{tabular}{|c|c|c|c|}
\hline \multirow[b]{2}{*}{ 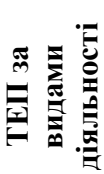 } & \multicolumn{3}{|c|}{ ТЕП за результуючим оптимальним значенням } \\
\hline & Які прямують до 1 & $\begin{array}{c}\text { Які мають } \\
\text { оптимальне } \\
\text { абсолютне значення }\end{array}$ & $\begin{array}{c}\text { Визначаються згідно } \\
\text { логічних суджень } \\
\text { експертів }\end{array}$ \\
\hline 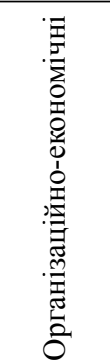 & $\begin{array}{l}\text { - капіталовіддача; } \\
\text { - матеріаловіддача; } \\
\text { - показник викори- } \\
\text { стання робочого часу } \\
\text { виробничих робіт- } \\
\text { ників. }\end{array}$ & $\begin{array}{l}\text { - капіталомісткість; } \\
\text { - матеріаломісткість; } \\
\text { - обсяг виготовленої } \\
\text { ТО; } \\
\text { - енергомісткість ТО; } \\
\text { - собівартість ТО; } \\
\text { - середньомісячна } \\
\text { заробітна плата робіт- } \\
\text { ників ІС ІПВ; } \\
\text { - продуктивність праці. }\end{array}$ & - \\
\hline 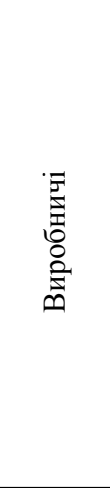 & $\begin{array}{l}\text { - використання облад- } \\
\text { нання; } \\
\text { - використання } \\
\text { виробничих площ; } \\
\text { - диференціації IB; } \\
\text { - безперервності IB; } \\
\text { - повторюваності IB; } \\
\text { - паралельності IB; } \\
\text { - прямоточності IB; } \\
\text { - універсалізації IB; } \\
\text { - гнучкості IB; } \\
\text { - автоматизації IB; } \\
\text { - рівень дефективності } \\
\text { ТО. }\end{array}$ & $\begin{array}{l}\text { - прогресивності } \\
\text { структури обладнання; } \\
\text { - використання площ } \\
\text { складу ІРК; } \\
\text { - спеціалізації IB; } \\
\text { - пропорційності IB; } \\
\text { - механізації інструмен- } \\
\text { тального виробництва; } \\
\text { - коефіцієнт викори- } \\
\text { стання виробничої } \\
\text { потужності; } \\
\text { - коефіцієнт дублю- } \\
\text { вання функцій. }\end{array}$ & - \\
\hline
\end{tabular}


Закінчення таблиці 1

\begin{tabular}{|c|c|c|c|}
\hline 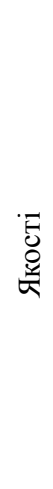 & $\begin{array}{l}\text { - витрати на якість } \\
\text { процесів ІС ІПВ; } \\
\text { - коефіцієнт стандар- } \\
\text { тизації ІПВ; } \\
\text { - показник уніфікації } \\
\text { IB; } \\
\text { - показник прогресив- } \\
\text { ності ТП ІВ; } \\
\text { - технологічний кое- } \\
\text { фіцієнт точності ТП } \\
\text { - рівень стандартиза- } \\
\text { ції ТО. } \\
\text { - рівень нормативного } \\
\text { забезпечення. }\end{array}$ & - & $\begin{array}{l}\text { - показник якості тех- } \\
\text { нічної документації } \\
\text { по ІС ІПВ; } \\
\text { - рівень якості ТО. }\end{array}$ \\
\hline 葛 & $\begin{array}{l}\text { - показник зайнятості } \\
\text { персоналу; } \\
\text { - показник рівня атес- } \\
\text { тації персоналу, що } \\
\text { працює з підвищеною } \\
\text { небезпечністю. } \\
\text { - рівень потенційної } \\
\text { небезпечності техно- } \\
\text { логічних процесів ТО } \\
\text { для навколишнього } \\
\text { середовища; }\end{array}$ & $\begin{array}{l}\text { - показник функціо- } \\
\text { нального розподілу } \\
\text { праці ITР та службов- } \\
\text { ців системи ІПВ. }\end{array}$ & $\begin{array}{l}\text { - рівень інструктажу } \\
\text { персоналу; } \\
\text { - рівень нормативної } \\
\text { документації в сфері } \\
\text { охорони праці; } \\
\text { - показник наявності } \\
\text { використання засобів } \\
\text { індивідуального } \\
\text { захисту; } \\
\text { - рівень потенційної } \\
\text { небезпечності; } \\
\text { - рівень планування і } \\
\text { контролю заходів. }\end{array}$ \\
\hline 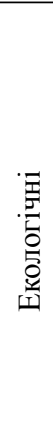 & $\begin{array}{l}\text { - частка скорочення } \\
\text { обсягів викидів від } \\
\text { загального обсягу; } \\
\text { - зменшення щіль- } \\
\text { ності викидів в атмос- } \\
\text { ферне повітря по } \\
\text { відношенню до певної } \\
\text { території; } \\
\text { - рівень відповідності } \\
\text { НД вимогам стандар- } \\
\text { тів навколишнього } \\
\text { середовища. }\end{array}$ & $\begin{array}{l}\text { - питомий показник } \\
\text { утворення відходів; } \\
\text { - зменшення кількості } \\
\text { днів, у які забруд- } \\
\text { нення атмосферного } \\
\text { повітря перевищувало } \\
\text { ГдК. }\end{array}$ & $\begin{array}{l}\text { - рівень змісту та } \\
\text { оформлення дока- } \\
\text { зової документації } \\
\text { екологічної безпеки } \\
\text { процесів; } \\
\text { - рівень виконання } \\
\text { вимог до захисту } \\
\text { навколишнього } \\
\text { середовища (по кож- } \\
\text { ному процесу). }\end{array}$ \\
\hline
\end{tabular}


Обмежуючими умовами при виконанні блоку 4 виступають:

$$
\mathrm{K}_{\mathrm{cr}} \rightarrow \min \text { та } \sum_{k=1}^{6} \gamma_{k}=1
$$

Блок 5 передбачає обчислення ймовірності реалізації обраної стратегії з допомогою застосування теорії марківських ланцюгів. Значення ймовірності реалізації обраної стратегії перевіряють на виконання умови перевищення необхідного рівня ймовірності:

$$
\sum_{j=1}^{n} p_{j} \geq 0,4
$$

Якщо значення розрахованої ймовірності менше достатнього рівня, вважають, що ймовірність перебігу процесів $\epsilon$ наднизькою. В такому разі необхідно розглянути альтернативні стратегії перебігу процесів IC IПВ, поки не буде позитивно виконана умова.

\section{5. Методика практичної реалізації запропонованої моделі}

У процесі розробки методики практичної реалізації запропонованої моделі визначено критерії вибору методу прогнозування, який найбільш адекватно враховує специфіку конкретного процесу ІПВ. На основі визначених критеріїв з використанням експертного методу попарного порівняння розроблено інструментарій з вибору раціонального методу прогнозування ТЕП та витрат на процеси IC IПВ. Запропонований метод дозволяє значно скоротити час на розробку прогнозуючої моделі щодо оцінювання якості перебігу процесів IC IПВ та ії результативності в цілому. Це дозволяе в повній мірі підвищити гнучкість IC IПВ вітчизняних промислових підприємств у швидкозмінних умовах.

Рішення в системі ІПВ, приймаються на основі інформації, яка $є$ продуктом IC IПВ, тобто первинна інформація перетворюється на результатну, придатну для прийняття рішень. В IC IПВ частина процедур формального перетворення первинної інформації в результатну автоматично виконується технічними засобами за заздалегідь заданими алгоритмами, без безпосереднього втручання людини. IC IПВ може повністю функціонувати в автоматичному режимі, але персонал IC IПВ визначає склад і структуру первинної та результатної інформації, порядок збору та реєстрації первинної інформації, контролює іії повноту і достовірність, визначає порядок виконання перетворень первинної інформації в результатну, контролює хід виконання процесу перетворень. 
Враховуючи вищезазначене, розглянутий в роботі алгоритм прийняття раціонального рішення в IC IПВ був реалізований на прикладі процесів тактичного рівня IC IПВ за допомогою засобів MS EXEL (застосовуються для автоматизації процесу збору первинної інформації щодо ТЕП IC IПВ), а також розробленого програмного забезпечення «Пошук найкоротшого шляху», що дозволяє за описаним у другому розділі алгоритмом Дейкстри отримати результатну інформацію для прийняття рішень. На основі отриманої інформації приймається відповідне раціональне рішення в IC IПВ. Підтвердженням вибору раціональної стратегії виступає розрахунок ймовірності їі виконання за допомогою застосування марківських ланцюгів.

Результати впровадження запропонованої Методики прийняття рішень в IC IПВ запропоновано оцінювати за допомогою порівняльної економічної ефективності: відношення собівартостей продукції при виконанні базової $C_{6}$ та прийнятої $C_{n}$ стратегії інструментозабезпечення:

$$
E=\frac{C_{6}}{C_{n p}}
$$

Наприклад, для розрахунку Е впровадження Методики прийняття рішень в IC IПВ на підприємстві ПАТ «СМНВО» були взяті дані для п’яти технологічних процесів виготовлення деталей за 2013-2014 pp.: номенклатура інструменту для їх виготовлення, кошторис собівартості деталі. Розрахунок наведений у [23], де доведено, що в середньому ефективність впровадження методики прийняття рішень в IC IПВ становить $13 \%$.

\section{6. Розроблення рекомендацій щодо впровадження та нормативного забезпечення IC IПВ}

Процес впровадження розробленого нормативно-методичного забезпечення IC IПВ та запропонованих рекомендацій по впровадженню розробленої моделі у виробництво на вітчизняних машинобудівних підприємствах дуже часто ускладнюється достатньо складною системою забезпечення співпраці різних структурних підрозділів та осіб, які відповідають за окремі види діяльності, особливо в умовах недостатньої забезпеченості виробництва необхідним для практичного використання сучасних інформаційних технологій оснащенням. Тому для мінімізації 
ризиків, пов'язаних з реалізацією моделі IC IПВ, запропонований алгоритм її розроблення та впровадження, показаний на рис. 6.

Також розділ містить матеріали 3 розробки проектів нормативних документів для кожного з етапів ЖЦ: проектування, розробки та виготовлення інструменту і оснащення, а також практичної реалізації розробленої в розділі 2 моделі прийняття рішень в IC IПВ.

На основі отриманих результатів теоретичних і практичних досліджень розроблено структури проекти двох стандартів організації України (СОУ): «Система управління якістю інструментальної підготовки виробництва в інформаційній системі підприємства» (поширюється

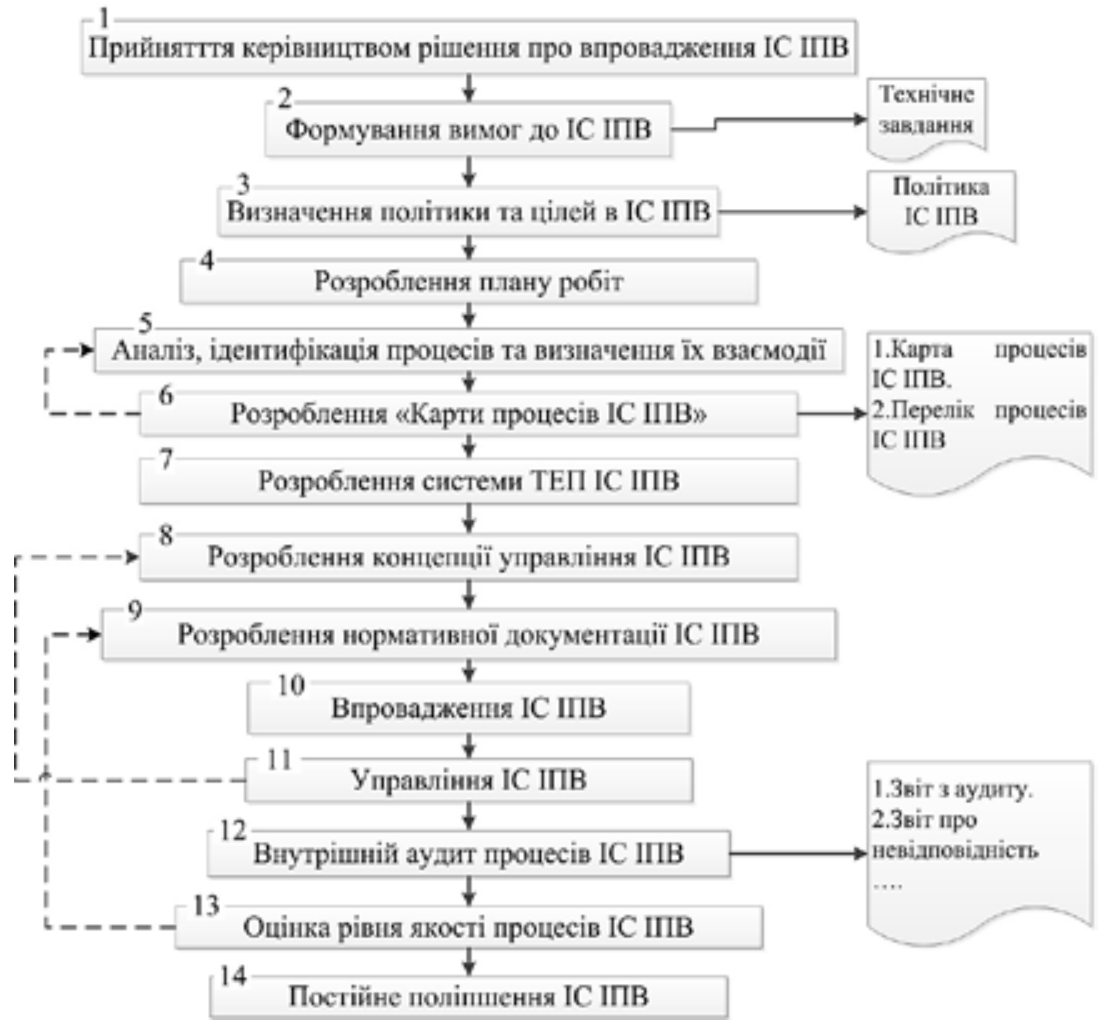

Рис. 6. Алгоритм впровадження системи IC IПВ 
на інформаційні системи ПАТ, використовувані в процесах життєвого циклу інструментальної підготовки виробництва та встановлює стадії і етапи проектування та розроблення ТО, виготовлення ТО, а також зміст робіт на кожному етапі) та «Експлуатація технологічного оснащення в умовах функціонування інформаційних систем» (стандарт поширюється на процес експлуатації технологічного оснащення та на застосування інтерактивних електронних технічних керівництв).

\section{7. Висновки}

В дослідженні вирішена актуальна науково-прикладна задача вдосконалення нормативного забезпечення процесів управління й оцінки якості ІПВ в умовах функціонування інформаційних технологій, вирішення якої забезпечить підвищення ефективності виробництва, включаючи підвищення надійності, зниження витрат і скорочення часу на інструментальне забезпечення і, відповідно, випуск продукції. На основі проведених досліджень можна зробити наступні висновки.

1.На основі аналізу сучасних тенденцій в області інформаційних технологій розроблено модель управління якістю інструментальної підготовки виробництва машинобудівного підприємства в умовах функціонування інформаційних технологій, яка дозволяє простежувати інформаційні зв'язки ІПВ. Доведено можливість застосування запропонованої моделі на будь-якому машинобудівному підприємстві.

2.Запропоновано критерії вибору раціональних методів прогнозування витрат на процеси ІПВ. На основі запропонованих критеріїв був розроблений інструментарій, який дозволяє врахувати специфіку конкретного процесу ІПВ при виборі методів прогнозування будь-яких показників на кожному етапі життєвого циклу технічного оснащення.

3. Запропоновано принципи класифікації витрат на якість процесів ІПВ машинобудівних підприємств. Це дозволило сформувати універсальну класифікацію витрат на якість ІПВ на будь-якому машинобудівному підприємстві.

4. Запропоновано систему ТЕП IC IПВ, які враховують специфіку протікання ії процесів. ТЕП IC IПВ доцільно класифікувати за видами діяльності: організаційно-економічні; виробничі; управління якістю; екологічні; соціальні. Запропонована система ТЕП IC IПВ може бути використана для раціоналізації діяльності з ІПВ різних машинобудівних підприємств. 
5.Запропоновано оцінювання ТЕП на основі застосування теорії нечітких множин. Цей метод дозволяє узгодити ТЕП трьох видів: ТЕП, що прямують до одиниці; ТЕП, які мають оптимальне абсолютне значення та ТЕП, що визначаються згідно логічних суджень експертів.

6.Запропоновано принципи формування інструментарію управління якістю ІПВ. На їх основі розроблена математична модель управління техніко-економічними показниками з врахуванням витрат на якість ІПВ, яка дозволить спрогнозувати найбільш ймовірний сценарій протікання процесів ІПВ, оперативно приймати управлінські рішення, тим самим мінімізувати витрати на ІПВ. При виборі раціонального рішення вперше запропоновано застосовувати коефіцієнт сталого розвитку IC IПВ. Доведена універсальність запропонованої моделі, застосовність не залежно від специфіки підприємства.

7. Доведено універсальність принципів формування нормативного забезпечення системи управління якістю ІПВ методами прогнозування в умовах інформаційних технологій.

8.На основі отриманих результатів досліджень розроблено структури проекти двох стандартів організації України (СОУ): «Система управління якістю інструментальної підготовки виробництва в інформаційній системі підприємства» та «Експлуатація технологічного оснащення в умовах функціонування інформаційних систем»

\section{Список літератури:}

1. Зеленцова Е.В., Зеленцова Н.Ф. Системный подход к инструментальному обеспечению предприятия. URL: http://www.instrument.spb.ru/zurnals/24/ zurnal_24Theme1.shtml

2. Губич Л., Иванец Г., Поздняков В. Компьютеризация инструментального производства - приоритетная задача промышленности. САПР и графика. 2001. № 2. C. 23-25.

3. Ивченко А.В. Управление качеством инструментальной подготовки производства многономенклатурного машиностроительного предприятия : дис. ... канд. техн. наук : спец. 05.01.02 «Стандартизация, сертификация и метрологическое обеспечение». КНУТД, 2009. 278 с.

4. Ивченко А.В., Залога В.А. Оптимизация организационной структуры инструментальной подготовки производства. Сучасні технології в машинобудуванні. 2008. Вип. 2. С. 238-248.

5. Костюк И.В. Интеллектуальная поддержка автоматизированной системы управления инструментообеспечением на машиностроительном 
предприятии : диссертация ... кандидата технических наук : спец. 05.13.06. Набережные Челны: Кам. гос. инж. экон. акад, 2009. 164 с.: ил.

6. Dynnyk O., Denysenko Y., Zaloga V., Ivchenko O., Yashyna T. Information Support for the Quality Management System Assessment of Engineering Enterprises. Advances in Design, Simulation and Manufacturing II. DSMIE 2019. Lecture Notes in Mechanical Engineering. 2020. Pages 65-74. doi: https://doi.org/10.1007/978-3-030-22365-6_7

7. Левин А.И., Судов Е.В. Концепция и технологии компьютерного сопровождения процессов жизненного цикла продукции Информационные технологии в наукоемком машиностроении. Компьютерное обеспечение индустриального бизнеса. 2001. С. 612-625.

8. Вайсман В.О. Моделі, методи та механізми створення і функціонування проектно-керованої організації : монографія. Київ : Науковий світ, 2009. 146 с.

9. Окулесский В.А. Функциональное моделирование - методологическая основа реализации процессного подхода. Москва : НИЦ CALS-технологий «Прикладная логистика», 2001. 56 с.

10. Чорна Н.О. Оцінка можливості застосування CALS-технологій до розвязання задач розподіленого управління. Управління розвитком складних систем : Збірник наукових праць. 2011. № 8. С. 97-100.

11. CALS. URL: http://uk.wikipedia.org/wiki/CALS

12. Левин А.И., Судов E.B. CALS-сопровождение жизненного цикла. Открытыле системы. 2001. № 3. С 58-62.

13. Бокс Дж., Дженкинс Г.М. Анализ временных рядов, прогноз и управление. Москва : Мир, 1974. 406 с.

14. Антохонова И.В. Методы прогнозирования социально-экономических процессов : учебное пособие. Улан-Удэ : Изд-во ВСГТУ, 2004. 212 с.

15. Ханк Д.Э., Райтс А.Дж., Уичерн Д.У. Бизнес-прогнозирование. Москва : Издательский дом Вильямс, 2003. 656 с.

16. Азгальдов Г. Г., Гличев А.В., Панов В.П. Что такое качество? Москва : Экономика, 1968. 135 с.

17. Crosby Ph.B. Quality bringt Gewink. Hamburg, 1986.

18. Торопцева А.Н., Герасимов Б.И. Экономический анализ системы менеджмента экологического качества промышленного предприятия: монография. Тамбов : Изд-во ТГТУ, 2006. 148 с.

19. FeigenbaumA.V. Quality and Productivity. Quality Progress. 1977. Nov, pp. 18-21.

20. Залесов В.А. Совершенствование системы технико-экономических показателей для управления деятельностью подразделений по машинной обработке информации промышленных предприятий : дис. ... к.э.н. : спец. 05.13.10. Ленинград, 1984. 183 с.

21. Залога В.О., Денисенко Ю.О., Івченко О.В. Система техніко-економічних показників інструментальної підготовки виробництва. Резание и инструмент в технологических системах : Междунар. науч.-техн. сб. Харьков : НТУ «ХПИ», 2015. № 85. С. 79-89.

22. Оре О. Теория графов / под ред. И.М. Овчинниковой. Издательство наука, 1980. 336 с. 
23. Денисенко Ю.О., Залога В.О., Івченко О.В., Обгрунтування ефективності впровадження методики прийняття рішень в інформаційній системі управління якістю інструментозабезпечення. Вісник Житомирського державного технологічного університету. 2015. № 1(72). С. 31-36.

\section{References:}

1. Zelentsova E.V., Zelentsova N.F. (2004). Sistemnyy podkhod k instrumental'nomu obespecheniyu predpriyatiya [A systematic approach to enterprise tooling]. Prommashinstrument, vol. 24. Retrieved from: http://www.instrument.spb.ru/ zurnals/24/zurnal_24Theme1.shtml (accessed 10 October 2019). (in Russian)

2. Gubich L., Ivsnets G.,Pozdnyakov V.(2001). Kompyuterizatsiya instrumentalnogo proizvodstva - prioritetnaya zadacha promyshlennosti [Computerization of tool production is a priority for industry]. CAD and graphics, vol. 2, pp. 23-25. (in Russian)

3. Ivchenko A.V. (2009). Upravlenie kachestvom instrumentalnoy podgotovki proizvodstva mnogonomenklaturnogo mashinostroitelnogo predpriyatiya [Quality management of tool preparation for the production of a multinomenclature engineering enterprise]. (PhD Thesis). Kyiv: Kyiv National University of Technology and Design. (in Russian)

4. Ivchenko A.V. (2008). Optimizatsiya organizatsionnoy struktury instrumentalnoy podgotovki proizvodstva [Optimization of the organizational structure of instrumental preparation of production]. Suchasni tehnologii v mashinobuduvanni [Modern technologies in mechanical engineering]. Kharkiv: NTU «KhPI», pp. 238-248.

5. Kostyuk I.V. (2009). Intellektualnaya podderzhka avtomatizirovannoy sistemy upravleniya instrumentoobespecheniem na mashinostroitelnom predpriyatii [Intellectual support of an automated tool management system at a machinebuilding enterprise]. ( $\mathrm{PhD}$ Thesis). Naberezhnye Chelny: Kama State Academy of Engineering and Economics. (in Russian)

6. Dynnyk O., Denysenko Y., Zaloga V., Ivchenko O., Yashyna T. (2020). Information Support for the Quality Management System Assessment of Engineering Enterprises. In: Ivanov V. et al. (eds) Advances in Design, Simulation and Manufacturing II. DSMIE 2019. Lecture Notes in Mechanical Engineering. Springer, Cham, pp. 65-74. doi: https://doi.org/10.1007/978-3-030-22365-6_7

7. Levin A.I., Sudov E.V. (2001). Kontseptsiya i tekhnologii kompyuternogo soprovozhdeniya protsessov zhiznennogo tsikla produktsii [The concept and technology of computer support of product life cycle processes]. Informatsionnye tekhnologii v naukoemkom mashinostroenii. Kompyuternoe obespechenie industrialnogo biznesa [Information technology in high technology engineering. Computer software for industrial business]. Kyiv: Technyka, pp. 612-625. (in Russian)

8. Vaisman V.O. (2009). Modeli, metody ta mekhanizmy stvorennia i funktsionuvannia proektno-kerovanoi orhanizatsii [Models, methods and mechanisms of creation and functioning of a project-managed organization]. (Monografy). Kyiv: Naukovy svit. (in Ukrainian)

9. OkulesskyV.A.(2001). Funktsionalnoemodelirovanie-metodologicheskaya osnova realizatsii protsessnogo podkhoda [Functional modeling is the 
methodological basis of the process approach implementation]. Moskow: CALS Technology Research Center "Applied Logistics". (in Russian)

10. Chorna N.A. (2011). Otsinka mozhlyvosti zastosuvannya CALStekhnolohiy do rozvyazannya zadach rozpodilenoho upravlinnya [Estimation of possibility of application of CALS-technologies to the solution of the problems of distributed management]. Upravlinnya rozvytkom skladnykh system [Management of complex systems development], vol. 8, pp. 97-100. (in Ukrainian)

11. CALS. Retrieved from: http://uk.wikipedia.org/wiki/CALS (accessed 20 May 2016).

12. Levin A.I., Sudov E.V. (2001). CALS-soprovozhdenie zhiznennogo tsikla [CALS life cycle support]. Otkrytye sistemy [Open systems], vol. 3, pp. 58-62.

13. Boks Dzh. (1974). Analiz vremennykh ryadov, prognoz i upravlenie [Time Series Analysis, Forecast and Management]. Moskow: Peace. (in Russian)

14. Antokhonova I.V. (2004). Metody prognozirovaniya sotsialno-ekonomicheskikh protsessov [Methods for predicting socio-economic processes]. Ulan-Ude: Publishing House of VSTU. (in Russian)

15. Khank D.E., Rayts A.Dzh., Uichern D.U. (2003). Biznes-prognozirovanie [Business forecasting]. Moscow: Publishing House Wiliams. (in Russian)

16. Azgaldov G.G., Glichev A.V., Panov V.P. (1968). Chto takoe kachestvo? [What is quality?]. Moskow: Economy. (in Russian)

17. Crosby Ph.B. (1986). Quality bringt Gewink. Hamburg.

18. Toroptseva A.N., Gerasimov B.I. (2006). Ekonomicheskiy analiz sistemy menedzhmenta ekologicheskogo kachestva promyshlennogo predpriyatiya [Economic analysis of the environmental management system of an industrial enterprise] (Monografy). Tambov: Publishing House of TSU. (in Russian)

19. Feigenbaum A.V. (1977). Quality and Productivity. Quality Progress, pp. 18-21.

20. Zalesov V.A. (1984). Sovershenstvovanie sistemy tekhniko-ekonomicheskikh pokazateley dlya upravleniya deyatelnostyu podrazdeleniy po mashinnoy obrabotke informatsii promyshlennykh predpriyatiy [Improving the system of technical and economic indicators for managing the activities of units for machine processing information of industrial enterprises] ( $\mathrm{PhD}$ Thesis). Leningrad. (in Russian)

21. Zaloga V., Denysenko Y., Ivchenko O. (2015). Systema tekhnikoekonomichnykh pokaznykiv instrumentalnoyi pidhotovky vyrobnytstva [System of technical and economic indicators of tool preparation]. Rezanye y ynstrument $v$ tekhnolohycheskykh systemakh [Cutting and tooling in technological systems]. Kharkiv: NTU «KhPI», vol. 85, pp. 79-89. (in Ukrainian)

22. Ore O. (1980). Teoriya grafov [Graph theory]. Moskow: Publishing House "Science". (in Russian)

23. Denysenko Y., Zaloga V., Ivchenko O. (2015). Obgruntuvannya efektyvnosti vprovadzhennya metodyky pryynyattya rishen $\mathrm{v}$ informatsiyniy systemi upravlinnya yakistyu instrumentozabezpechennya [Substantiation of effectiveness of implementation of decision-making methodology in the information system of quality management of the tool preparation]. Visnyk Zhytomyrskoho derzhavnoho tekhnolohichnoho universytetu [Bulletin of Zhytomyr State Technological University]. Zhytomyr: ZhSTU, vol. 1(72), pp. 31-36. (in Ukrainian) 